DOI https://doi.org/10.30525/978-9934-26-000-1-13

\title{
ОРГАНІЗАЦІЙНА СТРУКТУРА КОМУНІКАЦІЙНОГО ПІДРОЗДІЛУ ДЕРЖАВНОГО ОРГАНУ СЕКТОРУ БЕЗПЕКИ НА ПРИКЛАДІ MIHICTЕРСТВА ВНУТРІШНІХ СПРАВ УКРАЇНИ
}

\author{
Тимошов С. T. \\ аспірант кафедри теорії комунікачії, \\ реклами та зв'язків з громадськістю \\ Запорізький національний університет \\ м. Запоріжжя, Украӥна
}

Міністерство внутрішніх справ України (далі - МВС) - це ключовий державний орган виконавчої влади, що відповідає за формування та реалізацію політики у сфері захисту прав і свобод громадян, інтересів суспільства та держави від протиправних посягань, ведення боротьби із злочинністю, охорону громадського порядку, забезпечення громадської безпеки та безпеки дорожнього руху, тощо [3].

Комунікаційна діяльність держорганів України регулюється законодавством. Зокрема, Закон «Про інформацію» визначає, що державні органи зобов'язані «інформувати громадськість та засоби масової інформації про свою діяльність і прийняті рішення» [4]. Закон також постановляє, що суб'єкти владних повноважень зобов'язані визначити спеціальні підрозділи, відповідальні за забезпечення доступу до інформації.

У Міністерстві внутрішніх справ України таким підрозділом виступає Департамент комунікації МВС, який, у свою чергу, складається 3 сімох відділів. Це - відділ інформаційної політики та стратегічних комунікацій, відділ забезпечення онлайн комунікацій, відділ забезпечення внутрішніх комунікацій, відділ роботи продакшн-студії МВС, відділ моніторингу ЗМІ та аналізу, відділ роботи із запитами та зверненнями та відділ взаємодії з органами влади та громадськістю.

Основне завдання Департаменту комунікації - організація взаємодії органів системи МBC зі ЗМI та громадськістю задля інформування населення про результати роботи у сфері підтримання публічного порядку і безпеки в державі.

Департамент співпрацює практично 3 усіма провідними засобами масової інформації. Працівники Департаменту забезпечують вихід тематичних відеоматеріалів і телепрограм про діяльність органів системи МВС практично на всіх центральних телеканалах. Підрозділом напрацьовано сталу систему інформування населення про діяльність MBC. Для представників ЗМІ не рідше одного разу на тиждень організовуються брифінги та прес-конференції за участю керівництва, 
надається сприяння в отриманні коментарів посадових осіб, іншої актуальної інформації. До послуг журналістів та громадськості - широкий спектр інформації, яка щоденно розміщується на офіційному веб-сайті в мережі Інтернет, на сторінках у соціальних мережах та розсилається електронними мережами в десятки редакцій 3МI.

Основні завдання Департаменту комунікації визначені відповідним наказом МВC [2]. До них належить надання об'єктивної інформації про діяльність Міністерства, розвиток відкритості в діяльності відомства, співпраця зі ЗМІ та використання сучасних технологій задля більш ефективного інформування про діяльність держоргану.

У своїй діяльності працівники Департаменту послуговуються також й Комунікаційною стратегією МВС, підготованою до Стратегії розвитку системи МВС на період до 2020 року, затвердженої Урядом 15 листопада 2017 року [5]. Відповідно до комунікаційної стратегії, $\mathrm{MBC}$ - сервісний механізм, який робить усе, аби життя законослухняного громадянина було безпечним. Слоганом Міністерства обрано «Створюємо безпеку разом», а ключові цінності у роботі відомства «Твоя безпека. Твій захист. Твій сервіс».

Директор Департаменту комунікації МВС також відповідає за координування комунікаційної діяльності всіх органів виконавчої влади, діяльність яких спрямовується міністром внутрішніх справ: Національна поліція, Державна прикордонна служба, Держслужба з надзвичайних ситуацій, Державна міграційна служба та Нацгвардія.

Отже, на прикладі комунікаційного підрозділу Міністерства внутрішніх справ України можна побачити, що інформаційна діяльність державних органів, зокрема й органів сектору безпеки, координується законодавством України та внутрішніми наказами відомства. Як правило, у відомстві виокремлено спеціальний підрозділ, відповідальний за забезпечення інформування громадськості та ЗМІ. Такий підрозділ має чітко визначену структуру та завдання.

\section{Література:}

1. Мельник А. Ф. Менеджмент державних установ і організацій: навч. посібник. Київ : Професіонал, 2006. 464 с.

2. Про вдосконалення взаємодії органів внутрішніх справ із засобами масової інформації: Наказ МВС від 25.03.2010 № 88 / Міністерство внутрішніх справ України. 2010.

3. Про затвердження Положення про Міністерство внутрішніх справ України: Указ Президента України від 7 квітня 2011 р. № 383/2011 / Президент України. URL: https://zakon.rada.gov.ua/laws/ show/1138/2000\#Text (дата звернення: 11.11.2020). 
4. Про інформацію: Закон України від 2 жовтня 1992 р. № 2657-XII Верховна Рада України. URL: https://zakon.rada.gov.ua/laws/show/265712\#Text (дата звернення: 11.11.2020).

5. Про схвалення Стратегії розвитку органів системи Міністерства внутрішніх справ на період до 2020 року: Розпорядження Кабінету Міністрів України від 15 листопада 2017 р. № 1023-р. URL: https://zakon.rada.gov.ua/laws/show/1023-2017-p\#Text (дата звернення: 11.11.2020). 